\title{
Common mistakes in infant feeding: survey from a London borough
}

\author{
ROSAMOND A K JONES, ELIZABETH M BELSEY
}

British Medical fournal, 1978, 2, 112-115

\section{Summary and conclusions}

A survey of infant-feeding practices among 265 mothers of 12-week-old infants in a London borough showed that only 18 gave breast milk alone, 236 giving bottle feeds, and 197 solids. Serious mistakes in feed preparation were common, and only 51 mothers followed manufacturers' instructions exactly. Most mothers (239) had attended a well-baby clinic, but clinic staff gave conflicting advice on infant feeding.

Health workers must pay greater attention to educating mothers on the details of infant feeding if the risks of hypernatraemia and obesity are to be reduced.

\section{Introduction}

In recent years the many advantages of breast-feeding have been emphasised, ${ }^{1}$ and attempts made to encourage mothers to choose this method. ${ }^{2}$ Nevertheless, many women have a deep-rooted dislike of breast-feeding, ${ }^{3}$ and therefore attention must also be paid to reducing the hazards of artificial feeding. Some of these risks, such as increased susceptibility to infections and atopic diseases, cannot at present be reduced, but the hazards of hypernatraemia and overfeeding could well be lessened if mothers adopted a more scrupulous feeding regimen. Wilkinson $e t a l^{4}$ found that mothers and midwives had a cavalier approach to measuring powdered milks, and Taitz ${ }^{5}$ found that in a paediatric clinic in Sheffield $100 \%$ of 6 -week-old infants were already receiving solids and $56 \%$ of them were above the 90th centile for weight. A recent government working party ${ }^{1}$ recommended that the introduction of solids should be delayed until 4-6 months and that more care should be paid to preparing artificial milks. We decided to see how far these recommendations were being followed by mothers and health workers in an inner London borough.

\section{Methods}

The study was carried out in St Thomas's Health District in the London borough of Lambeth, on a sample of mothers whose babies

\footnotetext{
Department of Community Medicine, St Thomas's Hospital and Medical School, London SE1 7EH

ROSAMOND A K JONES, MRCP, senior house officer in community medicine and paediatrics (now registrar, department of child health, Hammersmith Hospital, London W12 OHS)

ELIZABETH M BELSEY, MSC, lecturer in medical statistics (now lecturer, department of community medicine, Middlesex Hospital Medical School, London W1P 1LB)
}

were born between February and June 1975. There were 881 live births during the study period. Infants who weighed less than $2.5 \mathrm{~kg}$ at birth and multiple births were excluded, and there were five neonatal deaths. To ensure adequate representation from all parts of the district, the remaining 812 mothers were stratified according to maternity and child health centre catchment areas. A random sample of 314 was then taken, but $34(11 \%)$ had moved outside the district, leaving 280 mothers drawn equally from the seven areas.

Home visits were carried out by one of us (RJ) 12 weeks after delivery. Mothers were asked how they fed their infants, how they prepared the infant's feeds, and what advice on feeding they had received. They were also asked what they thought their baby weighed. The babies were weighed on an infant beam balance, weights being recorded to the nearest $10 \mathrm{~g}$ below. Crown-heel length was measured to the nearest $5 \mathrm{~mm}$ below using a standard length-measuring board. At the start of the study a postal questionnaire was sent to all health visitors and doctors working in the maternity and child health centres in the district, asking what advice they gave about time of weaning.

\section{Results}

Completed questionnaires were obtained from 265 mothers (95\%). Reasons for non-response were illness of mother or baby in eight cases, failure to be traced in two, request of health visitor in two, refusal in two, and adoption in one. All mothers were interviewed between $11 \frac{1}{2}$ and $16 \frac{1}{2}$ weeks after delivery, most (246) being seen in the 13th week. Fifty $(98 \%)$ of the 51 health workers completed questionnaires. All differences reported below have a $\mathrm{P}$ value of less than $0 \cdot 05$.

CHOICE OF MILK

Breast-feeding was attempted by 165 mothers ( $62 \%$ ), but by 12 weeks $236(89 \%)$ were giving artificial milks, and $197(74 \%)$ solids, with only $18(7 \%)$ giving breast milk alone for 12 weeks. In all, 16 brands of milk were in use, $143(61 \%)$ using an unmodified powdered milk, $72(31 \%)$ a modified powdered milk, $8(3 \%)$ an evaporated milk, and $21(9 \%)$ fresh cow's milk. Some mothers regularly used two or more types of milk. Eighty-nine $(38 \%)$ had changed brands, some several times.

\section{PREPARATION OF ARTIFICIAL MILKS}

Two hundred and fifteen mothers used powdered milks and table I shows how they prepared them. Roughly scraping the scoop on the packet was common practice, although this has been shown to overfill the scoop. Seven mothers were not measuring the milk powder at all, simply guessing or judging by the colour. One mother was regularly adding salt and nutmeg to her baby's feeds. Eight women were using evaporated milk, and only two of them were diluting it correctly. Only 96 mothers $(43 \%)$ added the recommended amount of sugar. When the amounts of both milk and sugar used are considered, only 51 $(23 \%)$ followed the manufacturer's instructions exactly. A further $63(28 \%)$ measured the milk accurately, but deliberately added an extra ounce of water or too little sugar, often on their health visitor's advice, and for further analysis we classed these practices as "correct." Table II shows that inaccuracies were more likely with increasing parity. Regular attenders (two or more visits) at child health clinics 
TABLE I-How mothers of 12-week-old infants prepared powdered milk feeds

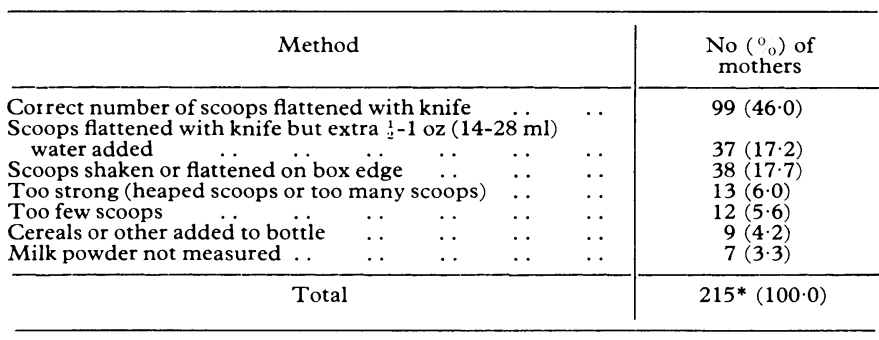

*Fifty mothers never used powdered milks.

were more likely to make up feeds accurately than those who rarely or never visited a clinic (96 out of $167\left(57^{\circ}{ }_{0}^{\circ}\right)$ as opposed to 18 out of 56 $(32 \%))$. Feed preparation was not related to social class, mothers from social classes I and II being just as prone to mistakes. Two hundred and forty-five $(92 \%)$ were aware of the dangers of over-strength feeds, though eight mothers thought that they should make feeds stronger if the baby was vomiting.

\section{INTRODUCTION OF SOLIDS}

Three mothers gave solids within the first two weeks of life. This figure increased steadily, until by 12 weeks $197(74 \%)$ had tried solids and $164(62 \%)$ were giving them regularly, the quantity ranging from a few teaspoonfuls of cereal to three or four jars of baby food a day. Early introduction of solids was associated with lower social class, less maternal education, and bottle-feeding, but was unrelated to attendance at child health clinics. The most common reason given for starting soli !s was that the baby seemed hungry $(141 ; 72 \%)$. Twentyseven mothers $\left(14^{\circ}{ }_{0}\right)$ started solids because they thought that their baby had reached the right age, and $18\left(9^{\circ}{ }_{0}\right)$ because they were advised to by their doctor or health visitor.

\section{CLINIC ADVICE}

Two hundred and thirty-nine mothers $\left(90^{\circ}{ }_{0}\right)$ attended their local child health clinic, $108\left(41^{\circ}{ }_{0}\right)$ having visited it four or more times. Primiparae were more likely to attend than multiparae $(95 \%$ and $87 \%$ respectively) but attendance was unrelated to social class. Table III shows that the commonest source of advice was the health visitor, although nearly two-thirds of mothers decided on their feeding methods themselves. Many used several sources of advice. Of 197 mothers who had started solids, only $100(51 \%)$ asked at the clinic before starting solids. Of these, 30 said that the clinic had suggested solids, 47 that the staff had agreed, and 23 that they were advised against it. The advice given by clinic staff was related neither to the age at which solids were introduced, nor to the baby's weight at 12 weeks.

Replies to the clinic staff questionnaires (table IV) show the wide range of advice given, with 40 health workers $(80 \%$ ) advising solids before 15 weeks, some as early as 4 weeks.

\section{WEIGHT OF INFANTS}

The weights of the infants at birth and at 12 weeks were compared with Tanner charts, ${ }^{6}$ as shown in table V. At birth the distribution of the boys' weights were similar to Tanner's standards, but the girls' weights were lower than would be expected, with 62 female infants $(45 \%)$ being grouped below the 25 th weight centile. The weight gain in both groups by 12 weeks was sufficiently large for the girls' weights to have reached the standard distribution, while 56 of the male infants $(41 \%)$ were found to be above the 75 th centile. The weight at 12 weeks and the weight gain from birth were both related to the strength of milk feeds prepared. Nevertheless, weight at 12 weeks was not associated with the age when solids were introduced, the quantity of solids given, or the duration of breast-feeding.

Mothers were asked whether they thought their baby was underweight, the correct weight, or overweight, and what opinion of the baby's weight, if any, had been expressed by their health visitor. Both sets of replies were strongly correlated with the infants' weight centiles as shown by Tanner charts (table VI), although the mother's opinion reflected the baby's weight more accurately than that of the health visitor. One hundred and sixty-two mothers $(61 \%)$ thought that plump babies were less healthy than slim ones. Despite this, the mother's opinion of her infant's weight was not associated with the age at which solids were started nor with the quantity of food given.

TABLE III-Data on where 265 mothers obtained advice on infant feeding

\begin{tabular}{|c|c|c|c|c|c|c|}
\hline & & & & & & $\begin{array}{l}\text { No }(\%) \text { of } \\
\text { mothers }\end{array}$ \\
\hline 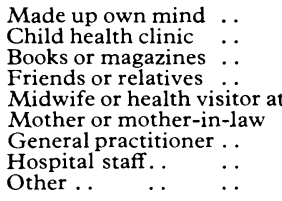 & $\begin{array}{l}\ldots \\
\therefore \\
\text { home } \\
\cdots \\
\cdots \\
\cdots\end{array}$ & $\begin{array}{l}\cdots \\
\cdots \\
\cdots \\
\cdots \\
\cdots \\
\cdots\end{array}$ & $\begin{array}{l}\ldots \\
\cdots \\
\cdots \\
\cdots \\
\cdots \\
\cdots\end{array}$ & $\begin{array}{l}\cdots \\
\cdots \\
\cdots \\
\cdots \\
\cdots \\
\cdots \\
\cdots\end{array}$ & $\begin{array}{l}\cdots \\
\cdots \\
\cdots \\
\cdots \\
\cdots \\
\cdots\end{array}$ & $\begin{array}{l}174(65 \cdot 7) \\
141(53 \cdot 2) \\
128(48 \cdot 3) \\
93(35 \cdot 1) \\
79(29 \cdot 8) \\
74(27 \cdot 9) \\
37(14 \cdot 0) \\
20(7 \cdot 5) \\
25(9 \cdot 4)\end{array}$ \\
\hline
\end{tabular}

\section{Discussion}

The study showed that 247 mothers $(93 \%)$ gave artificial feeds to their babies within the first 12 weeks of life. Two important hazards to the infant, those of incorrect feed preparation and overfeeding, were often encountered, though both may be avoided. As most maternity units use prepacked milks, it is especially important that all mothers, including those who are breast-feeding, are given careful instructions on feed preparation and an explanation of the hazards of inaccurate measurement before leaving hospital. Many brands of powdered milk are available which have different instructions for preparation and different-sized scoops. Since mothers change readily from one brand to another, the manufacturers should be strongly encouraged to standardise and simplify their instructions.

When this survey was carried out unmodified milks were still widely used despite their known high sodium content, and although these milks have recently been withdrawn, hypernatraemic dehydration still occurs in infants fed on low-solute milks. ${ }^{7}$ The numbers of mothers using fresh cow's milk is particularly worrying. In Sheffield, Smith ${ }^{8}$ found in a spot check on the sodium content of feeds that $57 \%$ were considerably overstrength. Although chemical assays are beyond the scope of routine child health clinics, simple questioning on feed preparation may easily be carried out. Our inquiries showed that

TABLE II-Relation between correct or incorrect preparation of powdered and evaporated milk feeds and parity. Figures are numbers (\%) of mothers

\begin{tabular}{|c|c|c|c|c|c|c|c|c|}
\hline \multirow{2}{*}{\multicolumn{4}{|c|}{ Preparation of feeds }} & \multicolumn{5}{|c|}{ Parity } \\
\hline & & & & \multirow{2}{*}{$\begin{array}{c}1 \\
51(60 \cdot 0) \\
19(22 \cdot 4) \\
15(17 \cdot 6)\end{array}$} & \multirow{2}{*}{$\begin{array}{c}2 \\
43(52 \cdot 4) \\
27(32 \cdot 9) \\
12(14 \cdot 6)\end{array}$} & \multirow{2}{*}{$\begin{array}{r}3 \\
12(42 \cdot 9) \\
5(17 \cdot 9) \\
11(39 \cdot 3)\end{array}$} & \multirow{2}{*}{$\begin{array}{c}\frac{1}{2} \\
8(28 \cdot 6) \\
11(39 \cdot 3) \\
9(32 \cdot 1)\end{array}$} & \multirow{2}{*}{$\begin{array}{c}\text { Total } \\
114(51 \cdot 1) \\
62(27 \cdot 8) \\
47(21 \cdot 1)\end{array}$} \\
\hline $\begin{array}{l}\text { Correct . . } \\
\text { Slightly incorrect } \\
\text { Seriously incorrect }\end{array}$ & $\begin{array}{l}. \\
\cdots\end{array}$ & $\begin{array}{l}\ldots \\
\cdots\end{array}$ & $\begin{array}{l}\ldots \\
\cdots\end{array}$ & & & & & \\
\hline \multicolumn{4}{|c|}{ Total } & $85(100 \cdot 0)$ & $82(100 \cdot 0)$ & $28(100 \cdot 0)$ & $28(100 \cdot 0)$ & $223 *(100 \cdot 0)$ \\
\hline
\end{tabular}

$\chi_{6}^{2}=16.63 ; P<0.02$.

*Forty-two mothers never used powdered or evaporated milk.

Correct $=$ Following manufacturer's instructions exactly, or adding $\frac{1}{2}-1 \mathrm{oz}(14-28 \mathrm{ml})$ water or too little sugar. Slightly incorrect $=$ Powdered milk scoops shaken flat or flattened on box edge, or too much sugar added. Seriously incorrect $=$ Feeds too weak, too strong, or with cereals or other additives. 
TABLE IV-Advice given by staff of child health clinic about ages at which infants should start solids. Figures are numbers (\%) of staff

\begin{tabular}{|c|c|c|c|c|c|c|c|c|c|}
\hline & & \multicolumn{7}{|c|}{ Age of infants (weeks) } & \multirow{2}{*}{ Total } \\
\hline & & $4-5$ & $6-7$ & $8-10$ & $11-14$ & $15-20$ & $\geqslant 20$ & Not known & \\
\hline $\begin{array}{l}\text { Bottle-fed infants } \\
\text { Breast-fed infants }\end{array}$ & $\begin{array}{l}\cdots \\
\cdots\end{array}$ & $\begin{array}{l}2(4) \\
1(2)\end{array}$ & $\begin{array}{l}3(6) \\
3(6)\end{array}$ & $\begin{array}{r}6(12) \\
10(20)\end{array}$ & $\begin{array}{l}29(58) \\
20(40)\end{array}$ & $\begin{array}{l}7(14) \\
8(16)\end{array}$ & $\begin{array}{l}3(6) \\
7(14)\end{array}$ & $\begin{array}{l}0 \\
1\end{array}$ & $\begin{array}{l}50(100) \\
50(100)\end{array}$ \\
\hline
\end{tabular}

TABLE V-Distribution of male and female infants according to weight centile at birth and at interview at 12 weeks

\begin{tabular}{|c|c|c|c|c|c|c|c|c|c|}
\hline & \multicolumn{2}{|c|}{ Weight centile ${ }^{6}$ : } & $>10$ & $10-24$ & $25-74$ & $75-89$ & $\geqslant 90$ & Total & Significance \\
\hline \multicolumn{10}{|c|}{ At birth } \\
\hline \multirow[t]{2}{*}{$\begin{array}{l}\text { No }(\%) \text { of boys } \\
\text { No }(\%) \text { of girls }\end{array}$} & $\begin{array}{l}\ldots \\
\ldots\end{array}$ & $\therefore$ & $\begin{array}{l}11(8 \cdot 6) \\
18(13 \cdot 1)\end{array}$ & $\begin{array}{l}25(19 \cdot 5) \\
44(32 \cdot 1)\end{array}$ & $\begin{array}{l}68(53 \cdot 1) \\
51(37 \cdot 2)\end{array}$ & $\begin{array}{l}14(10 \cdot 9) \\
16(11 \cdot 7)\end{array}$ & $\begin{array}{r}10(7 \cdot 8) \\
8(5 \cdot 8)\end{array}$ & $\begin{array}{l}128(100) \\
137(100)\end{array}$ & $\begin{array}{l}\chi^{2}{ }_{4}=4.28 ; 0.5>P>0.3 \\
\chi^{2}=35.96 ; P<0.001\end{array}$ \\
\hline & \multicolumn{8}{|c|}{ At interview } & \\
\hline $\begin{array}{l}\text { No }(\%) \text { of boys } \\
\text { No }(\%) \text { of girls }\end{array}$ & $\begin{array}{l}\ldots \\
\ldots\end{array}$ & $\ldots$ & $\begin{array}{r}7(5 \cdot 5) \\
10(7 \cdot 3)\end{array}$ & $\begin{array}{l}12(9 \cdot 4) \\
15(10 \cdot 9)\end{array}$ & $\begin{array}{l}53(41 \cdot 4) \\
72(52 \cdot 6)\end{array}$ & $\begin{array}{l}25(19 \cdot 5) \\
20(14 \cdot 6)\end{array}$ & $\begin{array}{l}31(24 \cdot 2) \\
20(14 \cdot 6)\end{array}$ & $\begin{array}{l}128(100) \\
137(100)\end{array}$ & $\begin{array}{l}\chi^{2}{ }_{4}=34.85 ; P<0.001 \\
\chi^{2}{ }_{4}=5.59 ; 0.3>P>0.2\end{array}$ \\
\hline
\end{tabular}

TABLE VI-Mothers' and health visitors' opinions of infants' weights by actual weight centile at interview. Figures are numbers ( $\%$ ) of infants

\begin{tabular}{|c|c|c|c|c|c|c|c|c|c|c|}
\hline & & & & & \multicolumn{6}{|c|}{ Weight centile } \\
\hline & & & & & $<10$ & $10-24$ & $25-74$ & $75-89$ & $\geqslant 90$ & Total \\
\hline \multicolumn{11}{|c|}{ Mother's opinion* } \\
\hline $\begin{array}{l}\text { Underweight } \\
\text { Correct weight } \\
\text { Overweight }\end{array}$ & $\begin{array}{l}. \\
\ldots\end{array}$ & $\begin{array}{l}\ldots \\
\cdots\end{array}$ & $\begin{array}{l}\ldots \\
\ldots\end{array}$ & $\begin{array}{l}\ldots \\
\cdots\end{array}$ & $\begin{array}{r}10(58 \cdot 8) \\
7(41 \cdot 2)\end{array}$ & $27(100 \cdot 0)$ & $\begin{array}{c}7(5 \cdot 6) \\
96(76 \cdot 8) \\
22(17 \cdot 6)\end{array}$ & $\begin{array}{l}28(62 \cdot 2) \\
17(37 \cdot 8)\end{array}$ & $\begin{array}{l}30(58 \cdot 8) \\
21(41 \cdot 2)\end{array}$ & $\begin{array}{c}17(6 \cdot 4) \\
188(70 \cdot 9) \\
60(22 \cdot 6)\end{array}$ \\
\hline \multicolumn{5}{|c|}{ Total } & $17(100 \cdot 0)$ & $27(100 \cdot 0)$ & $125(100 \cdot 0)$ & $45(100 \cdot 0)$ & $51(100 \cdot 0)$ & $265(100 \cdot 0)$ \\
\hline \multicolumn{11}{|c|}{ Health visitor's opinion ${ }^{\dagger}$} \\
\hline $\begin{array}{l}\text { Underweight } \\
\text { Correct weight } \\
\text { Overweight } \\
\text { Not known.. }\end{array}$ & $\begin{array}{l}\cdots \\
\cdots \\
\cdots\end{array}$ & $\begin{array}{l}\ldots \\
\cdots \\
\cdots\end{array}$ & $\begin{array}{l}\cdots \\
\cdots \\
\cdots\end{array}$ & $\begin{array}{l}. \\
\cdots \\
\cdots \\
\cdots\end{array}$ & $\begin{array}{l}5(29 \cdot 4) \\
6(35 \cdot 3) \\
1(5 \cdot 9) \\
5(29 \cdot 4)\end{array}$ & $\begin{aligned} 1 & (3 \cdot 7) \\
16 & (59 \cdot 3) \\
3 & (11 \cdot 1) \\
7 & (25 \cdot 9)\end{aligned}$ & $\begin{array}{c}3(2 \cdot 4) \\
56(44 \cdot 8) \\
15(12 \cdot 0) \\
51(40 \cdot 8)\end{array}$ & $\begin{array}{l}13(28.9) \\
10(22 \cdot 2) \\
22(48 \cdot 9)\end{array}$ & $\begin{array}{l}15(29 \cdot 4) \\
18(35 \cdot 3) \\
18(35 \cdot 3)\end{array}$ & $\begin{array}{c}9(3.4) \\
106(40 \cdot 0) \\
47(17.7) \\
103(38.9)\end{array}$ \\
\hline \multicolumn{5}{|c|}{ Total } & $17(100 \cdot 0)$ & $27(100 \cdot 0)$ & $125(100 \cdot 0)$ & $45(100 \cdot 0)$ & $51(100 \cdot 0)$ & $265(100 \cdot 0)$ \\
\hline
\end{tabular}

${ }^{*} \chi_{8}^{2}=111.94 ; P<0.001$
$\dagger \chi^{2}=19.93 ; P<0.001$

$49 \%$ of mothers were making important mistakes in preparing powdered or evaporated milk feeds. Many of these mothers attended clinics regularly, and yet the staff were apparently failing to take the opportunity of asking what methods were used and advising mothers about correct procedure. We found that consistently overstrength feeds were associated with increased weight gain, contrary to the findings of de Swiet et al. ${ }^{9}$

This survey was carried out one year after the Department of Health and Social Security's report on infant feeding was published, which recommended that solids should be introduced between 4 and 6 months of age. Despite this, 197 infants $(74 \%)$ had already received solids before 12 weeks. Many mothers had asked their doctor or health visitor for advice, but the replies were not related to the child's age. The average age at which clinic staff recommended solids ranged from 4 weeks onwards, and was inconsistent with the recent recommendations. Moreover, different staff at the same clinic held widely divergent views, which can serve only to increase the mother's confusion. Most babies were weighed regularly at the clinic, but advice on starting solids was unrelated to the baby's weight. If the time spent weighing babies is to be justified clinic cards should be redesigned to incorporate a centile chart.

We found that many mothers are still preparing feeds inaccurately and introducing solids too early. Staff in child health clinics should agree on an overall policy on infant feeding so that they can give consistent advice while keeping a flexible approach to the individual mother and baby. People working with infants should be aware of the frequent errors made in preparing feeds and take every opportunity to ask the mother to describe her method in detail. Only by explaining repeatedly to mothers about the dangers of overstrength feeds will the morbidity and mortality from hypernatraemia and obesity be reduced.
We thank Professor W Holland for his advice with the study and all the clinic staff and mothers who so willingly participated.

\section{References}

${ }^{1}$ Department of Health and Social Security, Present-Day Practice in Infant Feeding. London, HMSO, 1974.

${ }^{2}$ Sloper, K S, Elsden, E, and Baum, J D, Archives of Disease in Childhood, $1977,52,700$.

3 Jones, R A K, and Belsey, E M, Social Science and Medicine, 1977, 11, 175.

${ }_{4}^{4}$ Wilkinson, P W, et al, British Medical fournal, 1973, 2, 15.

${ }^{5}$ Taitz, L S, British Medical fournal, 1971, 1, 315.

${ }^{6}$ Tanner, J M, Whitehouse, R H, and Takaishi, M, Archives of Disease in Childhood, 1966, 41, 613.

7 Whaley, P, and Walker-Smith, J A, Lancet, 1977, 1, 51.

${ }^{8}$ Smith, B A M, British Medical fournal, 1974, 4, 741 .

${ }^{9}$ de Swiet, M, Fayers, P, and Cooper, L, Lancet, 1977, 1, 892.

(Accepted 31 March 1978)

Can fluphenazine hydrochloride (Moditen) be continued indefinitely without risk of undesirable effects?

Although fluphenazine may cause long-term effects such as persisting dyskinesias, the risk is small. The risks arising from the illnesses for which fluphenazine is used are considerable, and in such cases the drug should not be withheld on the basis of possible long-term side effects. Depressive illness may also supervene, but it is readily treatable. Patients receiving fluphenazine hydrochloride over a long period should be seen regularly to ensure that no early unwanted effects are developing. 